\title{
The Inhibitory Effect of Curcumin on Ornithine Decarboxylase against Hepatic Carcinoma
}

\author{
Abeer A. Khamis ${ }^{1 *}$, Amira H. Sharshar1, Amal H. Mahmoud², Tarek M. Mohamed ${ }^{1}$ \\ ${ }^{1}$ Biochemistry Division, Chemistry Department, Faculty of Science, Tanta University, Tanta, Egypt \\ ${ }^{2}$ Head Researcher of Special Food and Nutrition Department, Food Technology, Research Institute, Agricultural Research Center, \\ Giza, Egypt \\ Email: *abeer.khamis@science.tanta.edu.eg
}

How to cite this paper: Khamis, A.A., Sharshar, A.H., Mahmoud, A.H. and Mohamed, T.M. (2019) The Inhibitory Effect of Curcumin on Ornithine Decarboxylase against Hepatic Carcinoma. Journal of Biosciences and Medicines, 7, 127-145. https://doi.org/10.4236/jbm.2019.75015

Received: March 23, 2019

Accepted: May 17, 2019

Published: May 20, 2019

Copyright (C) 2019 by author(s) and Scientific Research Publishing Inc. This work is licensed under the Creative Commons Attribution International License (CC BY 4.0).

http://creativecommons.org/licenses/by/4.0/

\begin{abstract}
Curcumin the active component of turmeric is widely used as an anticancer agent for treating many human cancers. This study aimed at the extraction of curcumin from Curcuma Longa and investigates its therapeutic effect as ornithine decarboxylase (ODC) inhibitor in HepG2 cells. The proliferation of HepG2 cells was carried out by using the MTT assay. In addition, cell cycle analysis was evaluated by using the flow-cytometric technique. Our results showed that curcumin has the ability to inhibit the proliferation of HepG2 cells with IC50 of $24.79 \mu \mathrm{g} / \mathrm{ml}$ and induced G2/M cell cycle arrest. Moreover, it caused an elevation in the intracellular concentration of $\mathrm{Ca}^{2+}$. Moreover, in the curcumin administration the downregulation expression level of ODC and Bcl-2 genes $(\mathrm{p} \leq 0.05)$ was significant found. On the other hand, upregulation in the expression level of P53, Bax, and caspase- 3 genes $(p \leq 0.05)$. This study concluded that curcumin may be considered as a new saving candidate for the future progress of antitumor agents.
\end{abstract}

\section{Keywords}

Curcumin-HepG2 Cells-Apoptosis, Ornithine Decarboxylase, Bax, Cell Cycle

\section{Introduction}

Cancer is considered as a complex genetic disease that is caused primarily by environmental factors. The cancer-causing agents can be present in food and water, in the air, and in chemicals and sunlight that people are exposed to [1]. Primary liver cancer is considered the second most common cancer leading to death and sixth most diagnosed cancer worldwide [2]. Hepatocellular carcinoma is the vast malignant tumor it accounts for $85 \%-90 \%$ of primary liver cancers 
[3]. It is the fifth most common form of cancer; it ranks third as a death reason worldwide [4]. In some parts of the world, it is the most common form of internal malignancy and the most common cause of death from cancer [5].

Although surgery, chemotherapy, and radiotherapy are considered as the most common methods of cancer treatment [6]. The clinical findings of the different treatment methods aren't acceptable and the available anti-cancer drugs exhibit limited efficacy with many adverse effects and are also expensive [7]. Most of the chemotherapeutic drugs which are used conventionally were designed to hit a single intracellular target and the physiological and mechanistic deregulations responsible for cancer development involve hundreds of genes or signaling cascades so that it appears that multi-target drugs are requested to overcome complex human diseases for instance cancer. So that researcher becomes interested in evaluating the anti-cancer effects of natural compounds to be capable of understanding their mechanism of actions [8].

Curcumin is extracted from Curcuma longa (turmeric) rhizomes is the main ingredient in turmeric and curry [9]. Turmeric was used in China and India many years ago as traditional medicine [8]. Several studies have shown that curcumin exerts antioxidant, anti-inflammatory, anti-carcinogenic and chemopreventive activities on many tumor cells. The essential structure of curcumin is the feruloylmethane skeleton. This special structure is responsible for the antioxidant activity of the curcumin [10]. It consists of two benzene rings, one having a phenol hydroxy and the other having a phenol methoxy showing the ability of curcumin to act as a hydrogen donor eliminating oxygen free radicals [11]. Several studies have shown that curcumin possesses anti-proliferative and anti-carcinogenic properties in a wide variety of in vitro and in vivo studies. Curcumin influences cell death by multiple, interdependent processes. It exerts its anticancer activity by Modulating the expression level of several target genes. [12] [13] [14].

Ornithine decarboxylase (ODC; EC 4.1.1.17) is a pyridoxal phosphate (PLP)-dependent amino acid decarboxylase. It is homodimer containing two active sites [15]. ODC is the first enzyme in the biosynthesis of polyamines, it catalyzes the decarboxylation of ornithine to putrescine, it is also the rate-limiting enzyme [16]. The down-regulation of ODC results in increased activity of ODC and may result in malignant transformation of cells. High activity of ornithine decarboxylase is seen in many common cancers. ODC has a very short half-life 10 - 20 minutes in eukaryotes, which reflects the extremely rapid rate of ODC turnover so that its expression is tightly regulated. The regulation of ODC is found to be deregulated in various malignancies including liver tumors. So ODC has become a logical target for drug control and a promising target for cancer research [17]. Some studies reflected the ability of curcumin to induce apoptosis in a number of cancers by inhibiting the activity of ODC [18] [19]. In this study, we studied the ability of curcumin to induce apoptosis of HepG2 cells by downregulating the expression level of 
the ODC gene. Our results confirmed that curcumin inhibits the proliferation of HepG2 cells by regulation of the expression level of ornithine decarboxylase gene along with inducing the mitochondria-mediated pathway of apoptosis.

\section{Materials and Methods}

\subsection{Extraction of Curcumin from Curcuma longa}

Extraction of curcumin was performed according to the method explained by [20] using soxhlet extraction followed by column chromatography.

A JNS-CO Spectrum System 4100 LE FTIR spectrometer (Japan) was used for the analysis of a purified extract of Curcuma Longa. The spectral FTIR are measured at a mid-infrared region corresponding to wavenumbers of $4000-650$ $\mathrm{cm}^{-1}$ with a resolution of $4 \mathrm{~cm}^{-1}$ [21].

\subsection{Determination of Antioxidant Activities of Curcumin}

Total antioxidant activity was estimated according to the free radical diphenylpicrylhydrazyl (DPPH) method was described by [22].

\subsection{Cell Line and Cell Culture}

HepG2 cells (ATCC, Manassas, Virginia, USA; Cat.no. HB 8065) were cultured in DMEM medium (GIBCO, New York, USA; Cat.no.11995073) provided by $10 \%$ heat-inactivated fetal bovine serum (GIBCO, Grand Island, New York, USA; Cat.no.10099133), in addition 1\% antibiotic/antimycotic "penicillin/streptomycin" (Thermo Fisher Scientific; Waltham, MA, USA; Cat.no. SV30082) and 2\% L-glutamine (Invitrogen, Grand Island, New York, USA; Cat.no. 25030024 ) in a $95 \%$ humidity with $5 \%$ carbon dioxide incubator at $37^{\circ} \mathrm{C}$ [23].

\subsection{Cell Toxicity Determination by MTT Technique (Determination of $\mathrm{IC}_{50}$ )}

The anti-cancer activity of the curcumin was assessed using MTT assay [3-(4,5-Dimethylthiazol-2-yl)-2,5-diphenyltetrazolium bromide, Molecular Probes, Eugene, Oregon, USA; Cat.no.V-13154)]. HepG2 cells were seeded at a density of $1 \times 10^{4}$ cells/well $(100 \mu \mathrm{L} /$ well $)$ for $24 \mathrm{~h}$. The curcumin was applied separately at different concentrations to the wells achieving final concentrations ranging from 0 to $16 \mu \mathrm{M}$ and the cells were cultured for 24 and $48 \mathrm{~h}$. At the finale of incubation, after that $10 \mu \mathrm{L}$ of $12 \mathrm{mM}$ MTT stock solution $(5 \mathrm{mg} / \mathrm{ml}$ MTT in sterile PBS) was added to each well. The plate was incubated for four hours at $37^{\circ} \mathrm{C}$. MTT solution was aspirated and $100 \mu \mathrm{L}$ DMSO was added for 20 minutes. Negative control of $10 \mu \mathrm{L}$ of the MTT stock solution added to $100 \mu \mathrm{L}$ of medium alone was included. The absorbance was read on an ELISA reader at $570 \mathrm{~nm}$. The percentage of surviving cells was calculated as OD of curcumin-treated sample/OD of control $\times 100 \%$. Assays were carried out in triplicate on three in- 
dependent experiments. The inhibiting curcumin concentration of $50 \%$ of cells $\left(\mathrm{IC}_{50}\right)$ was calculated using the sigmoidal curve [23].

\subsection{Cell Cycle Assessment by Propidium Iodide Using Flow Cytometry}

HepG2 cells were grown at a density of $1 \times 10^{6}$ cells $/ \mathrm{ml}$ in 6-well plates and then treated with $0,10,20$, and $40 \mu \mathrm{mol} / \mathrm{L}$ concentrations curcumin for $24 \mathrm{~h}$. after that cells were harvested and fixed in $70 \%$ ethanol and stored at $4^{\circ} \mathrm{C}$ overnight. The fixed cells were centrifuged at $1000 \times \mathrm{g}$ for $5 \mathrm{~min}$ and washed with cold phosphate-buffered saline (PBS) three times. At last, cells were incubated with $50 \mu \mathrm{g} / \mathrm{mL}$ Propidium containing $8 \mu \mathrm{g} / \mathrm{mL}$ Ribonuclease $\mathrm{A}$ in the dark at $37^{\circ} \mathrm{C}$ for $30 \mathrm{~min}$. The DNA content of cells was quantified by flow cytometry [23].

\subsection{Determination of ODC Concentration on HepG2 Cells}

The concentration of ODC was assessed using Ornithine Decarboxylase ELISA Kit purchased from (Cusabio, USA) (following the manufacturer's protocol).

\subsection{Molecular Investigation}

\subsubsection{RNA Extraction from HepG2 Cells and cDNA Synthesis}

Culture cells collected from 6 well plates were prepared for RNA extraction using RNA extraction kits (Thermo Scientific, Fermentas, \#K0731) following the manufacturer's protocol. $5 \mu \mathrm{g}$ of template RNA was reverse-transcribed to cDNA using reverse transcription kits (Thermo Scientific, Fermentas, \#EP0451) following the manufacturer's protocol.

\subsubsection{Real-Time PCR}

RT-qPCR for each target gene (ODC gene, P53 gene, Bcl-2 gene, Bax gene, caspase-3 gene and the housekeeping gene (GAPDH)) was performed in a $25 \mu \mathrm{L}$ which contains the following: $3 \mu \mathrm{L}$ cDNA template (10 - $20 \mathrm{ng} / \mu \mathrm{L}), 2 \mathrm{X}$ Maxima SYBR Green/ROX qPCR Master Mix (12.5 $\mu \mathrm{L}), 1 \mu \mathrm{L}$ Primer forward $(10 \mu \mathrm{M}), 1$ $\mu \mathrm{l}$ Primer reverse $(0.1-0.5 \mu \mathrm{M}), 7.5 \mu \mathrm{L}$ Water, nuclease-free. The primers used in the amplification are shown in (Table 1) The final reaction mixture was placed in a Step One Plus real-time thermal cycler and the PCR program was performed in 45 Cycles with the PCR conditions as follow (Initial denaturation $95^{\circ} \mathrm{C} / 10 \mathrm{~min}$, Denaturation $95^{\circ} \mathrm{C} / 15 \mathrm{sec}$, Annealing $60^{\circ} \mathrm{C} / 30 \mathrm{sec}$ and Extension $72^{\circ} \mathrm{C} / 30 \mathrm{sec}$ ). The temperature was increased to $95^{\circ} \mathrm{C}$ to produce a melt curve at the end of the last cycle; the quantities critical threshold $(\mathrm{Ct})$ of the target gene was normalized with quantities $(\mathrm{Ct})$ of the house-keeping gene by used the $2^{-\Delta \Delta \mathrm{Ct}}$ method [24].

\subsection{Measurement of Intracellular Concentration of $\mathrm{Ca}^{2+}$ in HepG2 Cells}

Intracellular $\mathrm{Ca}^{+2}$ were assessed using Calcium Colorimetric Assay Kit following the manufacturer's protocol (Sigma Aldrich, Catalog Number MAK022). 
Table 1. Forward and reverse primers sequence for candidate genes.

\begin{tabular}{|c|c|c|c|c|}
\hline Gene & $\begin{array}{c}\text { Forward primer } \\
\left(' 5-{ }^{\prime}-3\right)\end{array}$ & $\begin{array}{c}\text { Reverse primer } \\
\left(' 5-{ }^{\prime}-3\right)\end{array}$ & $\begin{array}{l}\text { Size } \\
\text { (bp) }\end{array}$ & $\begin{array}{l}\text { Accession } \\
\text { number }\end{array}$ \\
\hline ODC & TTGCGGATTGCCACTGATGATTCC & ATCAGAGATTGCCTGCACGAAGGT & & \\
\hline P53 & AACAGTTCCTGCATGGGCGGC & AGGACAGGCACAAACACGCACC & 165 & NM_00054 \\
\hline Bax & TGCTTCAGGGTTTCATCCAG & GGCGGCAATCATCCTCTG & 170 & NM_001291428 \\
\hline Caspase3 & TTAATAAAGGTATCCATGGAGAACACT & TTAGTGATAAAAA TAGAGTTCTTTTGTGAG & & \\
\hline $\mathrm{Bcl} 2$ & AGGAAGTGAACATTTCGGTGAC & GCTCAGTTCCAGGACCAGGC & 146 & NM_000633 \\
\hline GAPDH & TGCACCACCAACTGCTTAGC & GGCATGGACTGTGGTCATGAG & 87 & NM_002046 \\
\hline
\end{tabular}

\subsection{Determination of the Antioxidant Activity of Curcumin in HepG-2 Cells}

L-Malondialdehyde (L-MDA) was determined according to the method of [25]. The activity of superoxide dismutase (SOD) was determined according to the method of [26]. One unit of enzyme activity is defined as the amount of enzyme that gave $50 \%$ inhibition of NBT reduction in one minute.SOD Activity: IU/mL $=\%$ inhibition $\times 3.75$. Catalase activity was evaluated according to the method described by [27]. The activity of GPX was determined using Glutathione Peroxidase Activity Colorimetric Assay Kit purchased from (Bio-diagnostic, Egypt) according to the method described by [28].

\subsection{Statistical Analysis}

All the data were expressed as means \pm S.E. The statistical significance was evaluated by one-way analysis of variance (ANOVA) using SPSS (18.0 software, 2011) and the individual comparisons were obtained by Duncan's multiple range test (DMRT). Values were considered statistically significant when $\mathrm{p}<0.05$.

\section{Results}

\subsection{Extraction and Determination of Curcumin}

Curcumin was extracted from Curcuma Longa as described previously. The extract was subjected to the TLC and was purified according to the Rf values which were $0.67,0.6$, and 0.506 for curcumin, demethoxycurcumin, and bisdemethoxycurcumin respectively. The curcumin structure was identified using FTIR spectrum. FTIR spectrum of curcumin showed a characteristic stretching band of $\mathrm{O}-\mathrm{H}$ at $3512 \mathrm{~cm}^{-1}$. The peak at $3014 \mathrm{~cm}^{-1}$ represents $\mathrm{C}-\mathrm{H}$ Stretching and 1602 $\mathrm{cm}^{-1}$ peak was assigned to $\mathrm{C}=\mathrm{C}$ symmetric aromatic ring stretching. The peak at $1506 \mathrm{~cm}^{-1}$ represents $\mathrm{C}=\mathrm{O}$, while enol C-O peak was obtained at $1280 \mathrm{~cm}^{-1}$ and benzoate trans-C-H vibration was at $962 \mathrm{~cm}^{-1}$ (Figure 1).

\subsection{Antioxidant Activity of Curcumin}

Using DPPH free radical scavenging activity the antioxidant activity of the curcumin was assessed by comparing the $\mathrm{IC}_{50}$ of the ascorbic acid. The $\mathrm{IC}_{50}$ of the curcumin was $3.7 \pm 0.20 \mu \mathrm{g} / \mathrm{mL}$ which is closer to the ascorbic acid $2.2 \pm 0.23$ 
$\mu \mathrm{g} / \mathrm{mL}$

\subsection{The Cytotoxicity of Curcumin by MTT Assay}

The cytotoxicity of curcumin on HepG2 cells was assessed by MTT assay. After treatment with Curcumin $(0$ to $16 \mu \mathrm{M})$ for $24 \mathrm{~h}$ and $48 \mathrm{~h}$, the proliferation of HepG2 cell was significant as shown in (Figure 2). The 50\% inhibiting concentration (IC50) was $24.79 \mu \mathrm{g} / \mathrm{mL}$.
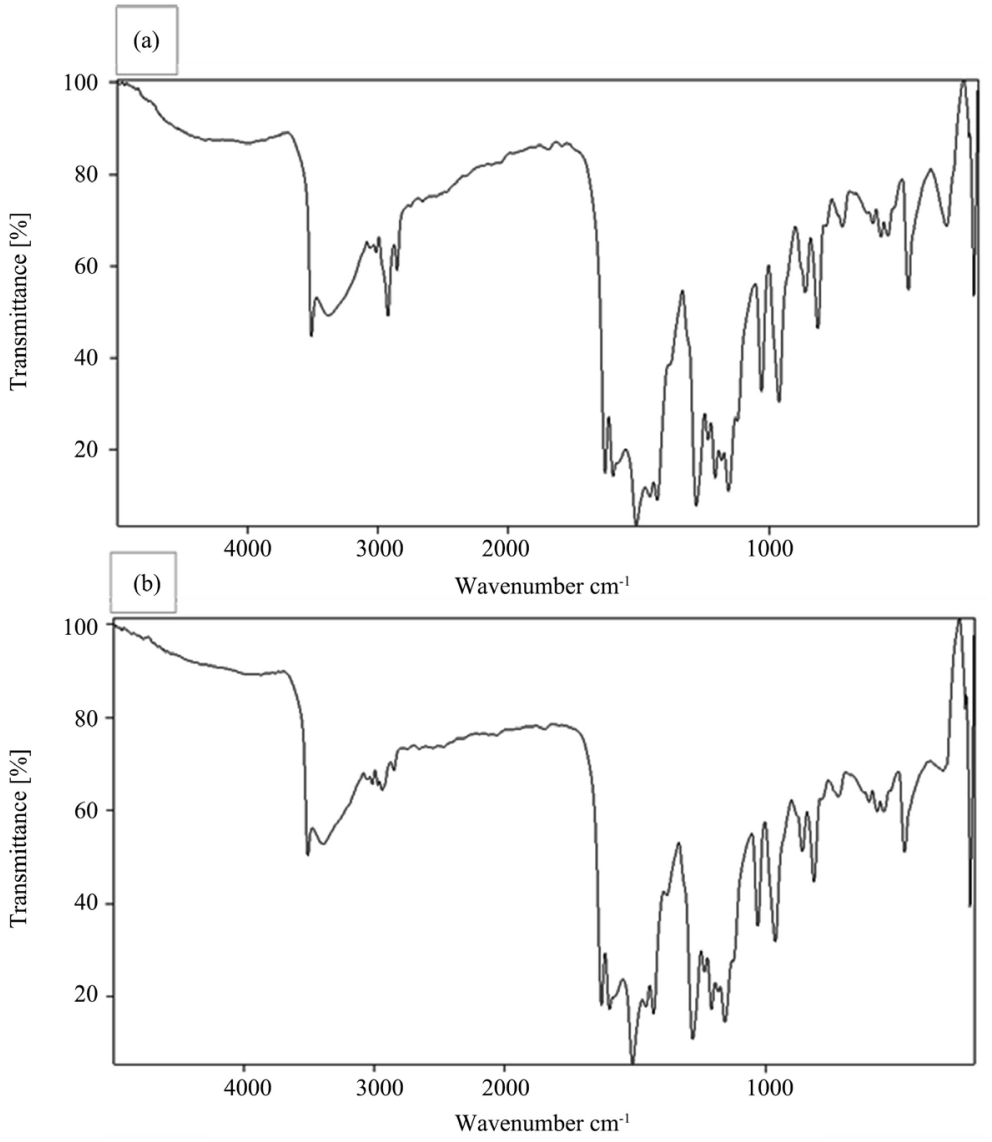

Figure 1. (a) FTIR spectrum of extracted curcumin from Curcuma Longa; (b) FTIR spectrum of standard curcumin.

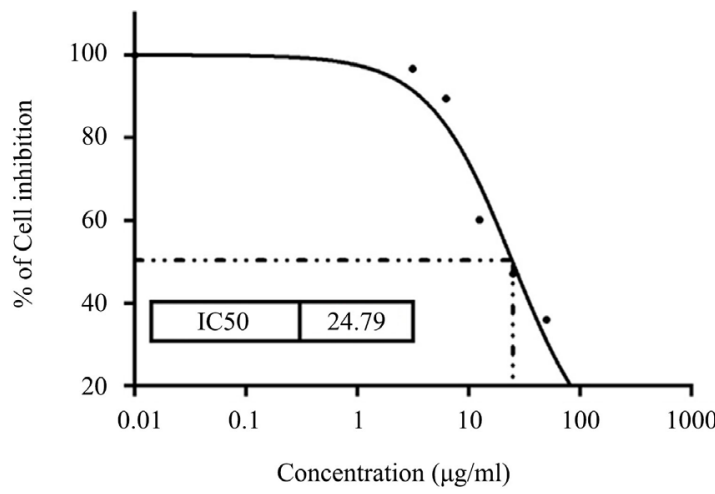

Figure 2. Analysis of cells viability. 


\subsection{Effect of Curcumin on the Cell Cycle in HepG2 Cells}

The effect of extracted curcumin on the cell cycle in HepG2 cells was estimated by flow cytometry using propidium iodide (PI). The obtained data revealed a significant number increase of HepG2 cells in G2/M phase in the treated cells compared with untreated cells with the highest levels in the standard group. In contrast, these treatments resulted in either a significant decrease the number of HepG2 cells in G0/G1 or no significant change in a number of cells in S phase as compared to G1 with lowest levels in G2 and highest in G3 (Table 2, Figure 3).

Means within the same column carrying different superscript letters are significantly different $(\mathrm{p} \leq 0.05)$ all groups versus the control group based on Duncan's multiple range test (DMRT). The results are present as the mean \pm standard deviation of three independent experiments.
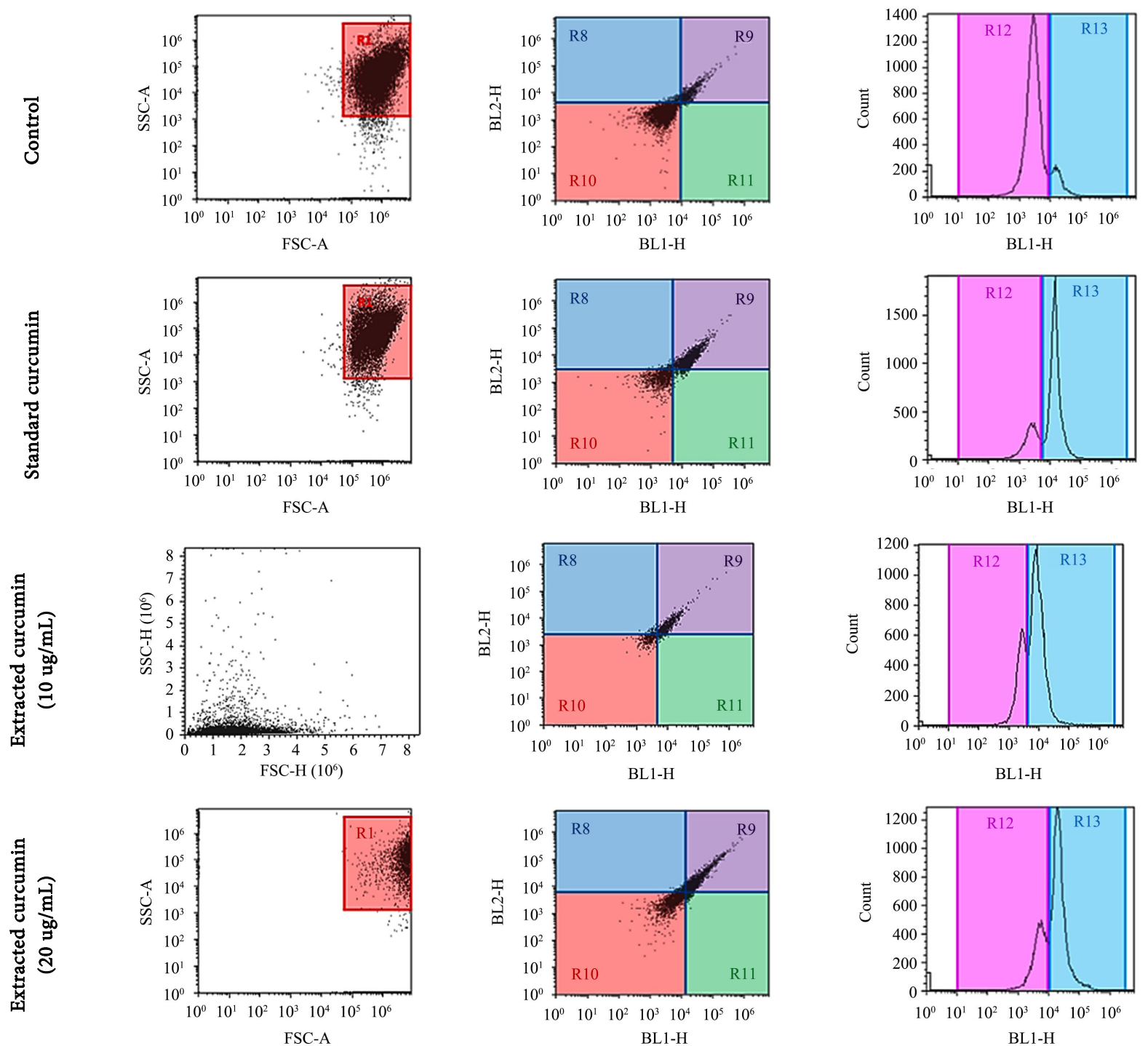

Figure 3. Effect of curcumin on cell cycle of HepG2 cells measured by flow cytometric method using the PI. The data are present as the mean \pm standard deviation of three independent experiments. 
Table 2. Average percentage of cell cycle phase in HepG2 cells.

\begin{tabular}{cccc}
\hline \multirow{2}{*}{ Groups } & \multicolumn{3}{c}{$\%$ of cell cycle phase } \\
\cline { 2 - 4 } & $\begin{array}{c}\text { G0/G1 phase } \\
(\text { Mean } \pm \text { SEM })\end{array}$ & $\begin{array}{c}\text { S phase } \\
(\text { Mean } \pm \text { SEM })\end{array}$ & $\begin{array}{c}\text { G2/M phase } \\
(\text { Mean } \pm \text { SEM })\end{array}$ \\
\hline $\begin{array}{c}\text { Control } \\
65 \%^{\mathrm{a}} \pm 2.11\end{array}$ & $20 \% \pm 1.76$ & $15 \%^{\mathrm{d}} \pm 1.48$ \\
$\begin{array}{c}\text { Standard curcumin } \\
(10 \mathrm{ug} / \mathrm{mL})\end{array}$ & $32 \%^{\mathrm{c}} \pm 1.90$ & $19 \% \pm 1.65$ & $49 \%^{\mathrm{a}} \pm 2.03$ \\
$\begin{array}{c}\text { Extracted curcumin } \\
(10 \mathrm{ug} / \mathrm{mL})\end{array}$ & $41 \%^{\mathrm{b}} \pm 2.10$ & $18 \% \pm 1.75$ & $41 \%^{\mathrm{c}} \pm 2.21$ \\
$\begin{array}{c}\text { Extracted curcumin } \\
(20 \mathrm{ug} / \mathrm{mL})\end{array}$ & $36 \%^{\mathrm{b}, \mathrm{c}} \pm 1.69$ & $19 \% \pm 1.72$ & $45 \%^{\mathrm{a}, \mathrm{b}} \pm 2.30$ \\
\hline
\end{tabular}

\subsection{Effect of Curcumin on ODC Concentration in HepG2 Cells}

The concentration of ODC in HepG2 cells of the control group was significantly increased $(\mathrm{p} \leq 0.05)$. This elevated concentration was significantly $(\mathrm{p} \leq 0.05)$ decreased after administration of standard curcumin at a dose of $10 \mathrm{ug} / \mathrm{mL}$ when applied for $24 \mathrm{~h}$. Similarly extracted curcumin at a dose of $10 \mathrm{ug} / \mathrm{mL}$ resulted in a significant decrease in ODC concentration when applied for $24 \mathrm{~h}$. The standard curcumin showed a significant reduction in ODC concentration than that extracted curcumin (Figure 4).

\subsection{Molecular Analysis}

Real-time PCR was used to detect the relative expression of ODC, P53, apoptosis-related genes (Bax and caspace3), and anti-apoptosis gene, Bcl2, that reflects the changes in transcription levels of these genes in HepG2 cells after administration of curcumin.

\subsubsection{Effect of Curcumin on the Relative Expression of ODC Genein HepG2 Cells}

Our finding emphasized a significant $(\mathrm{p} \leq 0.05)$ upregulation in the expression level of the ODC gene in HepG2 cells of control groups. This elevated expression was downregulated after administration of both standard and extracted curcumin at a dose of $10 \mathrm{ug} / \mathrm{mL}$ when applied for $24 \mathrm{~h}$ and $48 \mathrm{~h}$. Generally, the standard curcumin showed significantly lower expression than that of the extracted curcumin with better results at $48 \mathrm{~h}$ than $24 \mathrm{~h}$. on the other hand, the expression level of ODC gene showed no significant difference in treatment with a low dose $(10 \mathrm{ug} / \mathrm{mL})$ and high dose $(20 \mathrm{ug} / \mathrm{mL})$ (Figure 5).

\subsubsection{Effect of Curcumin on the Relative Expression of P53 Genein HepG2 Cells}

The significant upregulation in the expression level of the P53 gene in HepG2 cells after administration of as compared to of control groups in a time-dependent manner was indicated in data. In general, the standard curcumin showed significantly higher expression than that of the extracted curcumin with better results at $48 \mathrm{~h}$ than $24 \mathrm{~h}$. However, no significant difference in the expression level of P53 gene was shown in treatment with a low dose $(10 \mathrm{ug} / \mathrm{mL})$ and high dose $(20 \mathrm{ug} / \mathrm{mL})$ (Figure 6). 


\subsubsection{Effect of Curcumin on the Relative Expression of the Bax Genein HepG2 Cells}

Our data revealed a significant upregulation in the expression level of the Bax gene in HepG2 cells after administration of curcumin in a time-dependent manner as compared to control groups (Figure 7). In general, the standard curcumin showed significantly higher expression than that of the extracted curcumin with better results at $48 \mathrm{~h}$ than $24 \mathrm{~h}$. However, no significant difference in the expression level of Baxgene was shown in treatment with a low dose (10 $\mathrm{ug} / \mathrm{mL})$ and high dose $(20 \mathrm{ug} / \mathrm{mL})$.

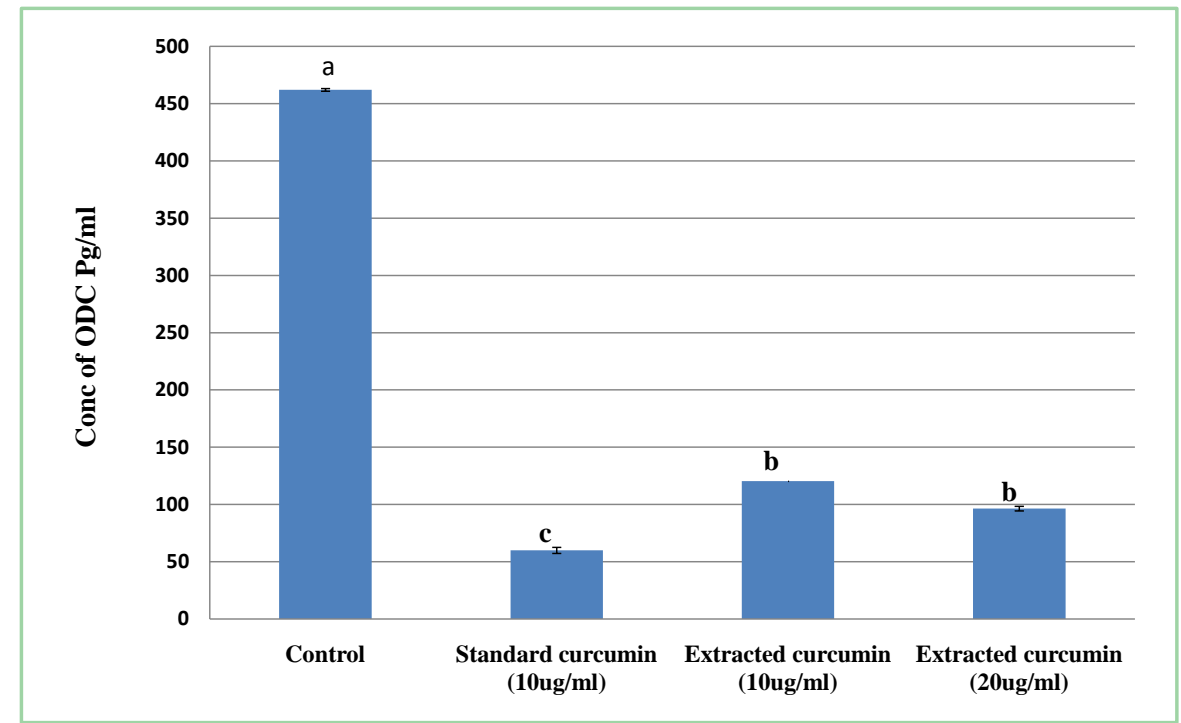

Figure 4. Effect of curcumin on ODC concentration in HepG2 cells. Means above the columns carrying different superscript letters are significantly different $(\mathrm{p} \leq 0.05)$.

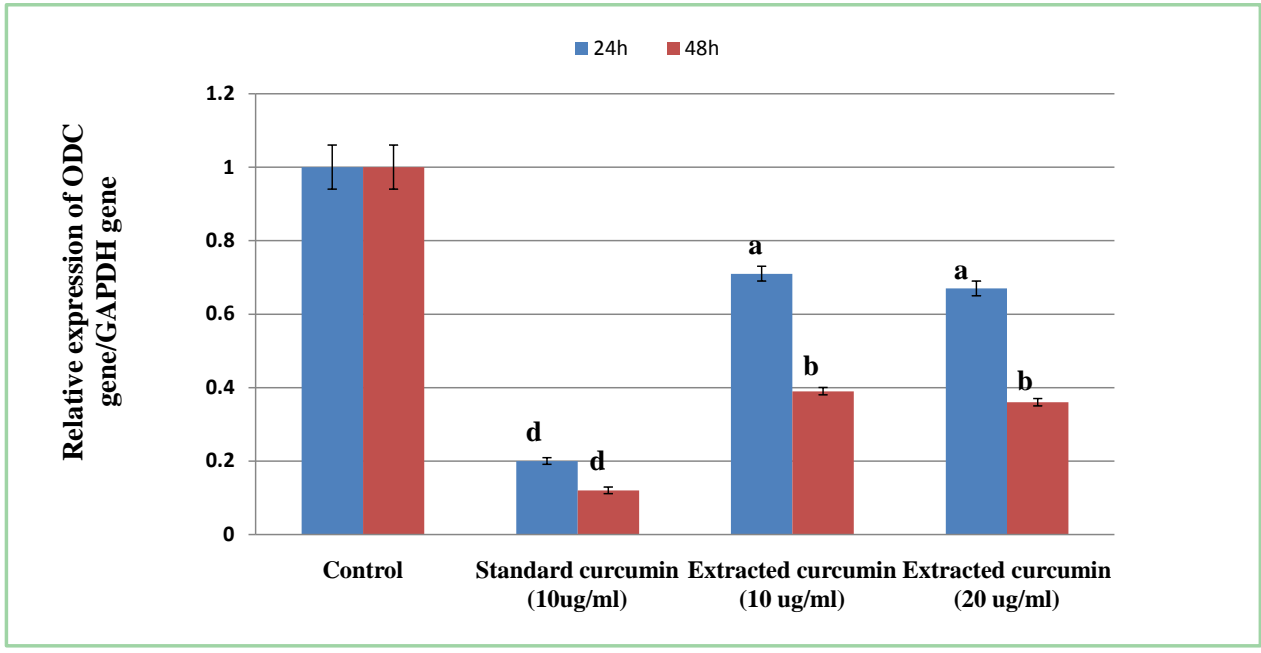

Figure 5. Graphical presentation of real-time quantitative PCR analysis of the expression of OCD gene in HepG2 cells after administration of curcumin for $24 \mathrm{~h}$ and $48 \mathrm{~h}$. The data are present as the mean \pm standard deviation of three independent experiments. Means within the same column carrying different superscript letters are significantly different ( $\mathrm{p}$ $\leq 0.05$ ) all groups versus the control group. 


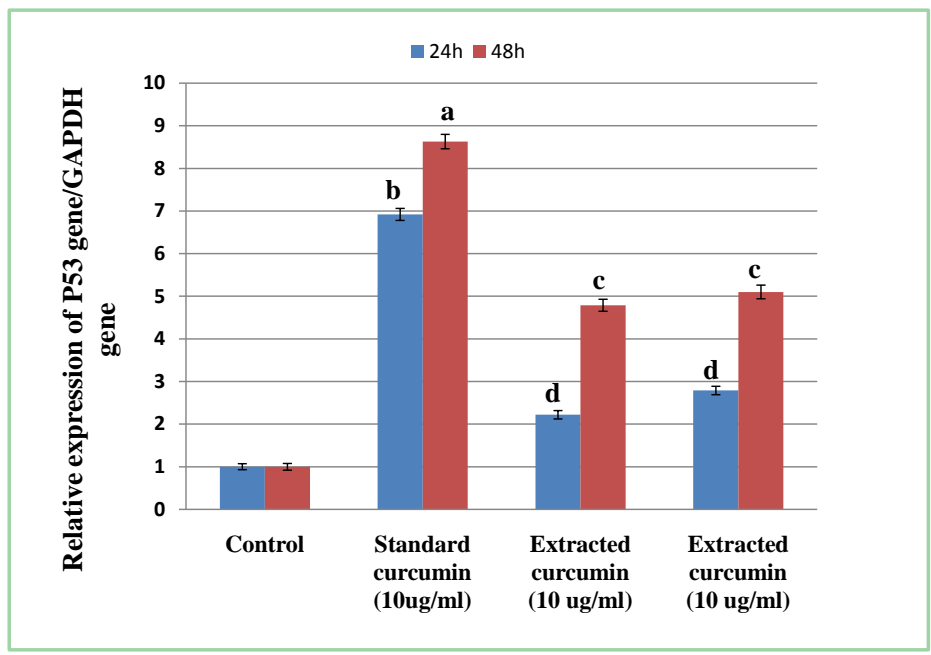

Figure 6. Graphical presentation of real-time quantitative PCR analysis of the expression of P53 gene in HepG2 cells after administration of curcumin for $24 \mathrm{~h}$ and $48 \mathrm{~h}$. The results are present as the mean \pm standard deviation of three independent experiments. Means within the same column carrying different superscript letters are significantly different $(\mathrm{p} \leq 0.05)$ all groups versus the control group.

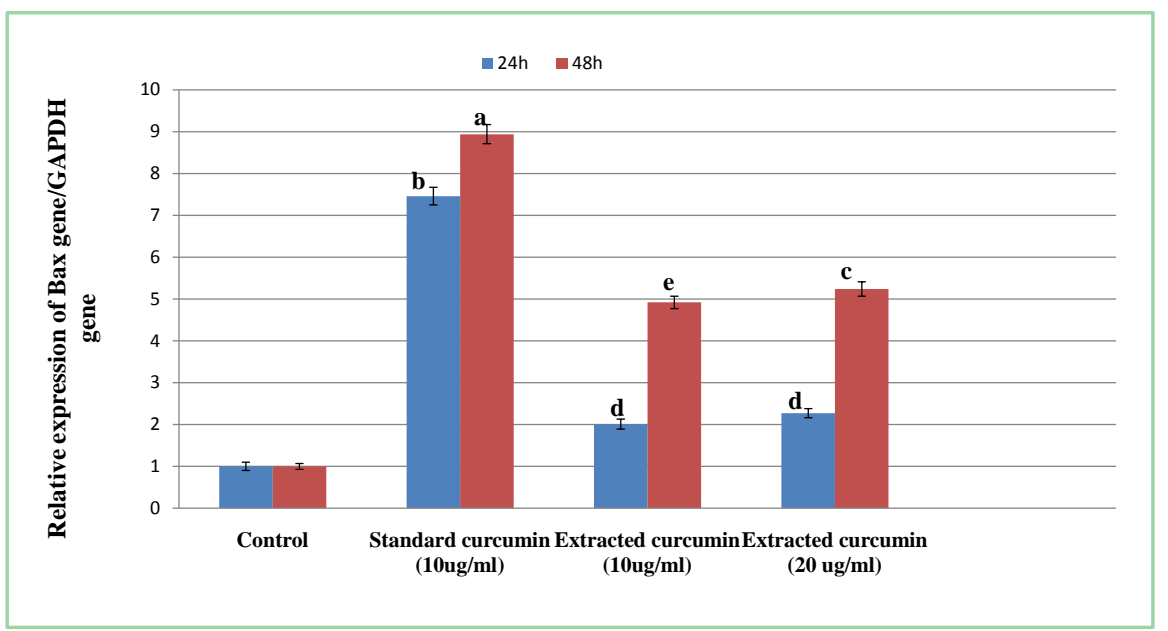

Figure 7. Graphical presentation of real-time quantitative PCR analysis of the expression of Bax gene in HepG2 cells after administration of curcumin for $24 \mathrm{~h}$ and $48 \mathrm{~h}$. The results are present as the mean \pm standard deviation of three independent experiments. Means within the same column carrying different superscript letters are significantly different ( $\mathrm{p} \leq 0.05)$ versus the control group all groups versus the control group.

\subsubsection{Effect of Curcumin on the Relative Expression of Caspase 3 Genein HepG2 Cells}

Data confirmed that a significant upregulation in the expression level of the caspase3 gene in HepG2 cells after administration of curcumin in a time-dependent manner as compared to control groups. In general, the standard curcumin showed significantly higher expression than that of the extracted curcumin with better results at $48 \mathrm{~h}$ than $24 \mathrm{~h}$. However, no significant difference in the expression level of caspase 3 gene was shown in treatment with a low dose $(10 \mathrm{ug} / \mathrm{mL})$ and high dose (20 ug/mL) (Figure 8). 


\subsubsection{Effect of Curcumin on the Relative Expression of Bcl2 Genein HepG2 Cells}

The results revealed a significant upregulation in the expression level of the $B c h$ gene in HepG2 cells of control groups which were downregulated after administration of curcumin at a dose of $10 \mathrm{ug} / \mathrm{mL}$ when applied for $24 \mathrm{~h}$ and $48 \mathrm{~h}$. In general, the standard curcumin showed significantly lower expression than that of the extracted curcumin with better results at $48 \mathrm{~h}$ than $24 \mathrm{~h}$. However, no significant difference in the expression level of $\mathrm{Bcl} 2$ gene was shown in treatment with a low dose $(10 \mathrm{ug} / \mathrm{mL})$ and high dose $(20 \mathrm{ug} / \mathrm{mL})$ (Figure 9).

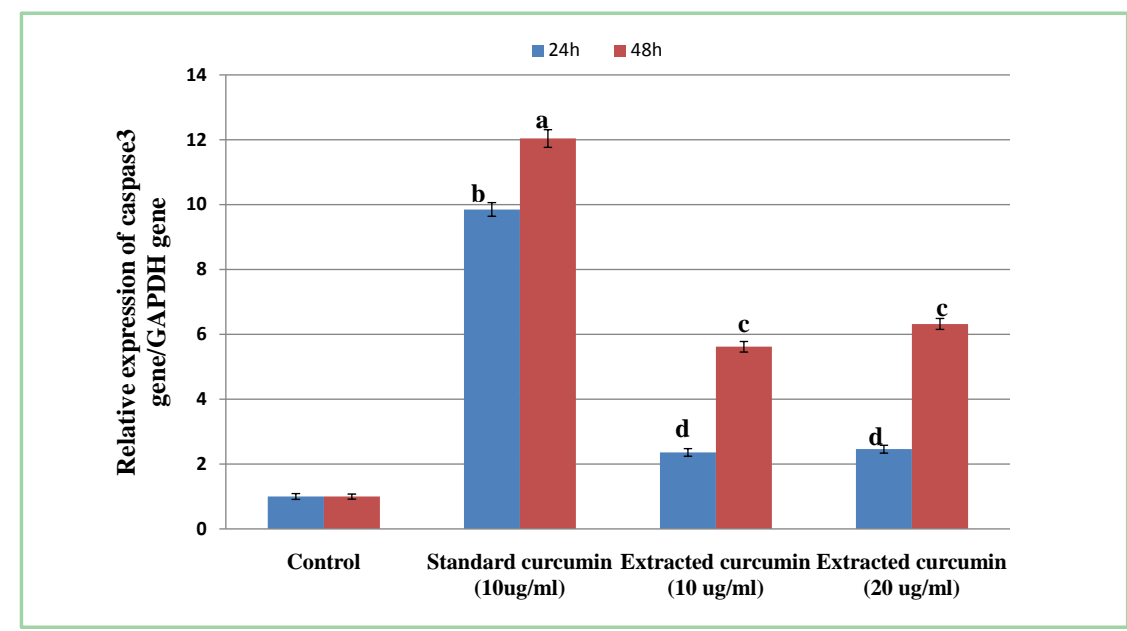

Figure 8. Graphical presentation of real-time quantitative PCR analysis of the expression of caspase 3 gene in HepG2 cells after administration of curcumin for $24 \mathrm{~h}$ and $48 \mathrm{~h}$. The data are present as the mean \pm standard deviation of three independent experiments. Means within the same column carrying different superscript letters are significantly different $(\mathrm{p} \leq 0.05)$ all groups versus the control group.

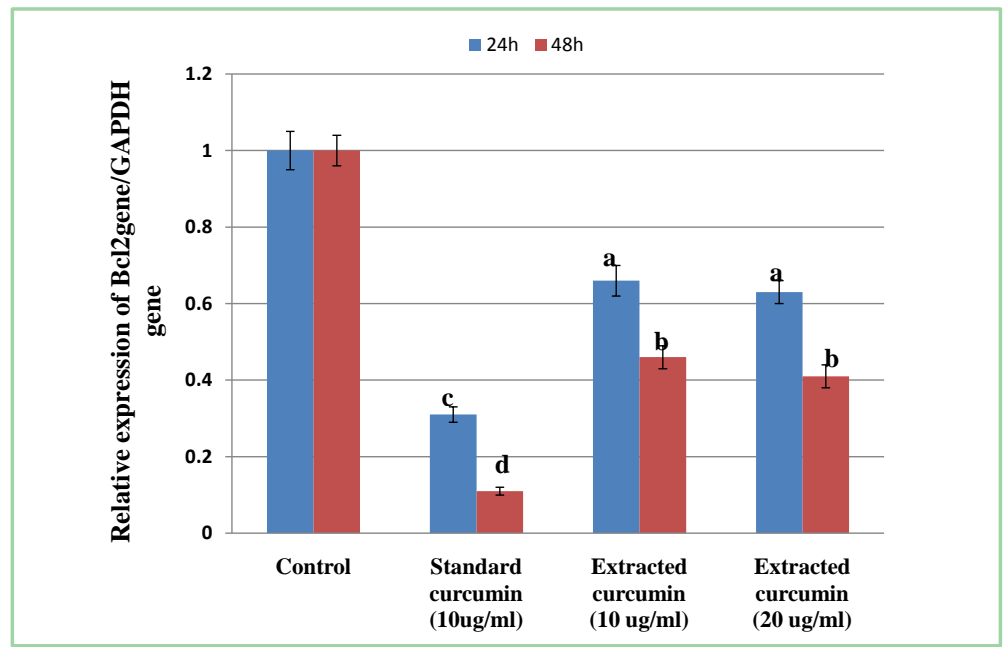

Figure 9. Graphical presentation of real-time quantitative PCR analysis of the expression of Bcl2 gene in HepG2 cells after administration of curcumin for $24 \mathrm{~h}$ and $48 \mathrm{~h}$. The results are present as the mean \pm standard deviation of three independent experiments. Means within the same column carrying different superscript letters are significantly different $(\mathrm{p} \leq 0.05)$ all groups versus the control group. 


\subsection{Effect of Curcumin on Intracellular Concentration of $\mathrm{Ca}^{2+}$ in HepG2 Cells}

The significant $(\mathrm{p} \leq 0.05)$ decrease in the intracellular concentration of $\mathrm{Ca}^{2+}$ in HepG2 cells of control groups was illustrated in our data. This reduced expression was significantly elevated after administration of curcumin at a dose of 10 $\mathrm{ug} / \mathrm{mL}$ when applied for $24 \mathrm{~h}$ and $48 \mathrm{~h}$ as compared to the control group. In general, the standard curcumin showed a significant higher $\mathrm{Ca}^{2+}$ concentration than that of the extracted curcumin with better results at $48 \mathrm{~h}$ than $24 \mathrm{~h}$. However, no significant difference in the $\mathrm{Ca}^{2+}$ concentration was shown in treatment with a low dose $(10 \mathrm{ug} / \mathrm{mL})$ and high dose $(20 \mathrm{ug} / \mathrm{mL})$ (Figure 10).

\subsection{Assessment of the Antioxidant Effect of Curcumin}

\subsubsection{Effect of Curcumin on L-Malondialdehyde (L-MDA)}

This results showed that a significant $(\mathrm{p} \leq 0.05)$ increase in the level of L-MDA in HepG2 cells of control groups. This elevated level was significantly ( $\mathrm{p} \leq 0.05)$ decreased after administration of standard curcumin at a dose of $10 \mathrm{ug} / \mathrm{mL}$ when applied for $24 \mathrm{~h}$. Similarly, the extracted curcumin (at a dose of 10 and 20 $\mathrm{ug} / \mathrm{mL}$ ) resulted in a significant decrease in L-MDA concentration when applied for $24 \mathrm{~h}$ as compared to the control group. In general, the standard curcumin showed a significant lower L-MDA concentration than that of the extracted curcumin with no significant difference in the L-MDA concentration was shown in treatment with a low dose $(10 \mathrm{ug} / \mathrm{mL})$ and high dose $(20 \mathrm{ug} / \mathrm{mL})$ (Figure 11).

\subsubsection{Effect of Curcumin on Superoxide Dismutase (SOD) Level in HepG2 Cells}

A significant ( $\mathrm{p} \leq 0.05)$ decrease in the level of SOD in HepG2 cells of control groups was shown. This reduced level was significantly ( $p \leq 0.05$ ) elevated after

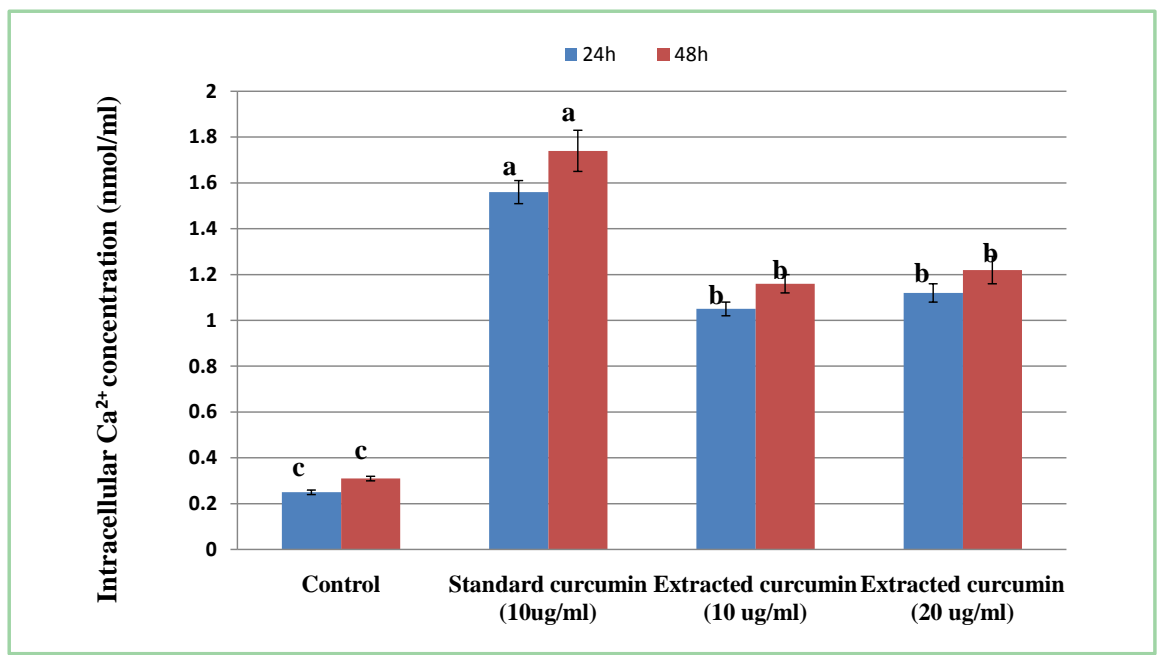

Figure 10. Effect of curcumin on $\mathrm{Ca}^{2+}$ concentration in HepG2 cells. The results are present as the mean \pm standard deviation of three independent experiments. Means above the columns carrying different superscript letters are significantly different $(p \leq 0.05)$ all groups versus the control group. 


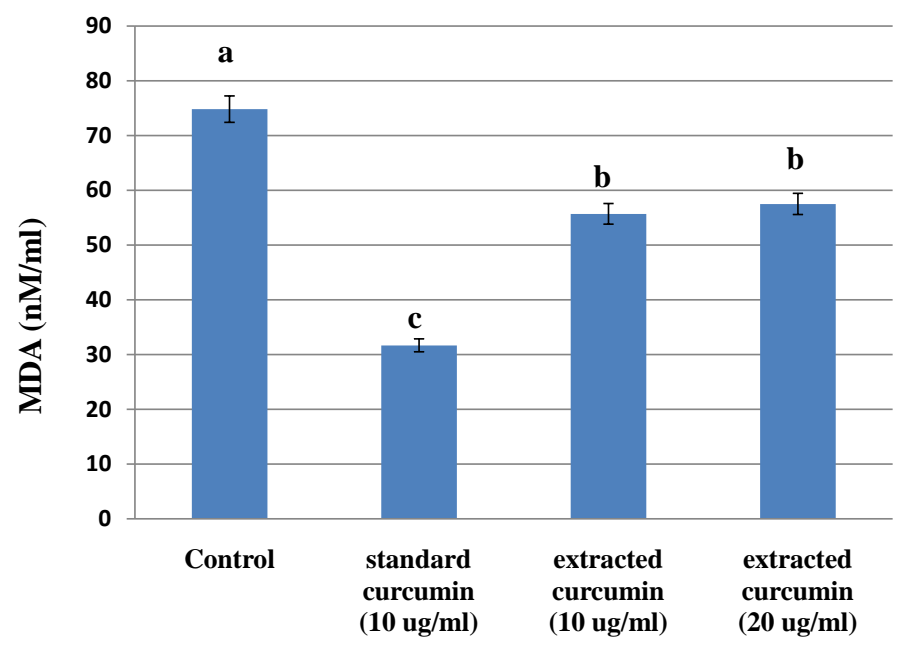

Figure11. Effect of curcumin on MDA concentration in HepG2 cells, Means within the same column carrying different superscript letters are significantly different $(p \leq 0.05)$.

administration of standard curcumin at a dose of $10 \mathrm{ug} / \mathrm{mL}$ when applied for 24 h. Similarly, the extracted curcumin (at dose of 10 and $20 \mathrm{ug} / \mathrm{mL}$ ) resulted in a significant increase in SOD level when applied for $24 \mathrm{~h}$ as compared to control group with no significant difference in the SOD concentration was shown in treatment with low dose $(10 \mathrm{ug} / \mathrm{mL})$ and high dose $(20 \mathrm{ug} / \mathrm{mL})$ (Figure 12).

\subsubsection{Effect of Curcumin on Catalase (CAT) Level in HepG2 Cells}

Our results confirmed a significant $(\mathrm{p} \leq 0.05)$ decrease in the level of CAT in HepG2 cells of control groups. This reduced level was significantly $(p \leq 0.05)$ elevated after administration of standard curcumin at a dose of $10 \mathrm{ug} / \mathrm{mL}$ when applied for $24 \mathrm{~h}$. Similarly, the extracted curcumin (at a dose of 10 and 20 $\mathrm{ug} / \mathrm{mL}$ ) resulted in a significant increase in CAT level when applied for $24 \mathrm{~h}$ as compared to the control group. In general, the standard curcumin showed a significant higher CAT level than that of the extracted curcumin with higher levels of CAT in cells treated with high dose $(20 \mathrm{ug} / \mathrm{mL})$ than cells treated with a low dose (10 ug/mL) (Figure 12).

\subsubsection{Effect of Curcumin on Glutathione Peroxidase (GPX) Level in HepG2 Cells}

Our data indicated a significant $(\mathrm{p} \leq 0.05)$ decrease in the level of GPX in HepG2 cells of control groups. This reduced level was significantly $(p \leq 0.05)$ elevated after administration of standard curcumin at a dose of $10 \mathrm{ug} / \mathrm{mL}$ when applied for $24 \mathrm{~h}$. Similarly, the extracted curcumin (at a dose of 10 and $20 \mathrm{ug} / \mathrm{mL}$ ) resulted in a significant increase in GPX level when applied for $24 \mathrm{~h}$ as compared to the control group. In general, the standard curcumin showed significantly higher levels of GPX than that of the extracted curcumin with no significant difference in the GPXlevels was shown in treatment with a low dose $(10 \mathrm{ug} / \mathrm{mL})$ and high dose $(20 \mathrm{ug} / \mathrm{mL})$ (Figure 12). 


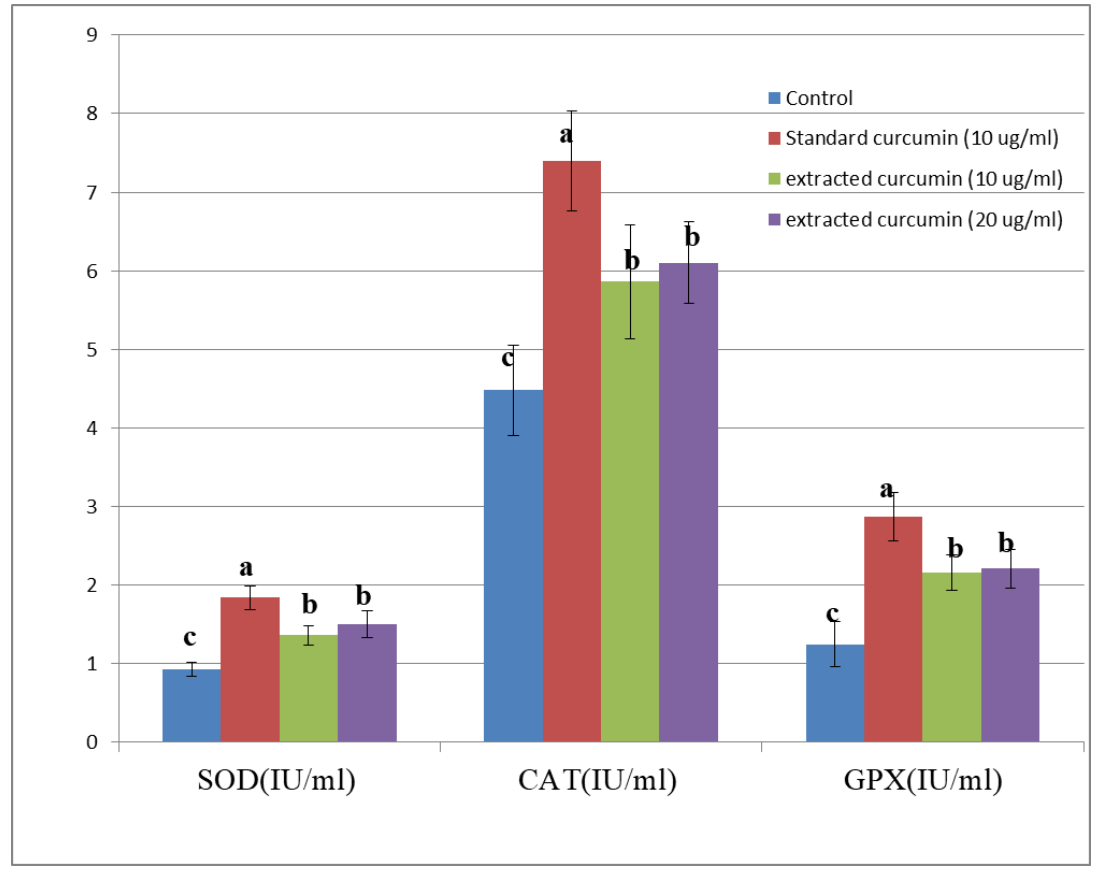

Figure 12. Effect of curcumin on the activity of SOD, CAT and GPX activity in HepG2 cells, for each parameter means within the same column carrying different superscript letters are significantly different $(\mathrm{p} \leq 0.05)$.

\section{Discussions}

The hepatocellular carcinoma (HepG2) cell line was selected to assess the inhibitory effect curcumin on ornithine decarboxylase owing to treatment of hepatocellular carcinoma. The finding of this study illustrated curcumin has the ability to downregulate the expression level of the ODC gene, inhibit HepG2 cell proliferation and promote apoptosis. It is well known that hepatocellular carcinoma (HCC) is one of the most common malignancies ranking fifth most common cancer all over the world. [29] The study demonstrated the several natural products extracted from medicinal plants have been studied for their antioxidant and anti-cancer effects by inhibiting the proliferation, invasion, and metastasis of cancer cells. On the other hand, several types of research have revealed the mechanisms of their action, much research is still needed. [30] The study confirmed the curcumin which is extracted from the rhizomes of Curcuma longa sp. has received attention as a potential agent in cancer therapy. [31] The study revealed the accumulating evidence shows that curcumin has a diverse range of molecular targets, and therefore acts upon numerous molecular and biochemical cascades. [32] Indicated the molecular targets for curcumin include inflammatory cytokines, transcription factors, gene products related to cell invasion and others. [33] Confirmed the biosynthetic pathway of polyamines, the ODC is considered as the rate-limiting enzyme that appears to have a vital role in cell proliferation, differentiation, and neoplastic transformation. The induction of ODC has been suggested to play a significant role in tumor promotion. It is commonly upregulated in hepatocellular carcinoma. Therefor ODC inhibition 
was shown to be a promising tool for screening inhibitors of tumorigenesis [19].

In this study, the antiproliferative activity of curcumin was evaluated by MTT assay and discovered that curcumin effectively inhibited the growth of HepG2 cells at $24 \mathrm{~h}$ with $\mathrm{IC}_{50}(24.79 \mu \mathrm{g} / \mathrm{mL})$. On the basis of this finding, we decided to find out the mechanism of cell death caused by curcumin treatment, cell-cycle analysis by flow cytometer showed that curcumin treatment induced a dose-dependent accumulation of HepG2 cells in G2/M phase with accompanied losses from the G0/G1 phase. But the S-phase population was not significantly increased [23]. These results suggested that curcumin caused a cell-cycle arrest in G2/M phase. These results were in accordance with results of on HepG2 cells and [34] on pancreatic cancer cells which revealed that curcumin-induced cell cycle arrest at G2/M phase and apoptosis in both of them.

In order to elucidate the molecular mechanism of the ability of curcumin to induce cell cycle arrest and cause apoptosis, the expression of a number of genes was tested after the administration of curcumin. On studying the effect of curcumin on the relative expression of ODC gene in HepG2 cells results revealed upregulation in the expression level of the ODC gene in HepG2 cells of control groups and this elevated expression was downregulated after administration of curcumin in a time-dependent manner. This indicates that curcumin may intercept the growth-promoting and mutagenic function of polyamines resulting in inhibition of the growth of HepG2 cells and thus lead to apoptosis of the cells. This finding was similar to the results of [18] which suggested that curcumin-induced apoptosis in human promyelocytic leukemia HL-60 cells occurs by a mechanism of down-regulating ODC. Our finding indicated that treatment with curcumin-induced apoptosis of the tumor cells by the upregulation in the expression level of the P53 gene in HepG2 cells after administration of curcumin in a time-dependent manner. This result agrees with the previous studies that also reflected the role of curcumin in upregulating P53 protein expression in cancer cells of lymphoma-bearing mice [35], human multiple myeloma cell line RPMI 8226 cells [36] and vascular smooth muscle cell line, A7r5 [37].

The present study investigated the apoptotic effect of curcumin on HepG2 cells by studying the effect of curcumin on the expression of the genes of the apoptotic proteins Bax and caspase-3 and the anti-apoptotic protein Bcl-2. Bax promotes cell apoptosis while $\mathrm{Bcl}-2$ prevents apoptosis by blocking the translocation of cytochrome $\mathrm{c}$ [38] the decrease of Bcl-2/Bax ratio is followed by the activation of caspase-3, the release of cytochrome c. [39]. The data showed a significant upregulation expression level of both Bax and Caspase- 3 genes in HepG2 cells after administration of curcumin, while the results showed upregulation expression level of the $\mathrm{Bcl} 2$ gene in HepG2 cells of control groups which were downregulated after administration of curcumin, thereby decreasing the $\mathrm{Bcl}-2 / \mathrm{Bax}$ ratio. The Bcl-2 family has been shown to be a P53 target, Bax is up-regulated in a number of systems during P53-mediated apoptosis [40]. So curcumin can regulate the expression of Bcl-2 family proteins either through regulating the expression of a P53 protein or directly resulting cytochrome $\mathrm{c}$ re- 
lease from the mitochondria and then caspase- 3 activation leading to cell apoptosis, this all indication reflects the role of curcumin in inducing apoptosis through the mitochondria-mediated pathway.

In this study, we also studied the effect of curcumin on intracellular calcium levels and the results showed a significant decrease in the intracellular concentration of $\mathrm{Ca}^{2+}$ in HepG2 cells of control groups which were elevated after administration of curcumin in a time-dependent manner. These results were in accordance with the results of [41] that suggested that curcumin-induced apoptosis and cell cycle arrest in colorectal cancer cells by increasing intracellular calcium levels. Calcium overload has been shown to play a critical role in the mechanism of initiation and regulation of cell apoptosis. [42] Calcium overload has a great effect on mitochondria as mitochondria take up cytosolic $\mathrm{Ca}^{2+}$ resulting in mitochondrial $\mathrm{Ca}^{2+}$ overload, which results in mitochondrial dysfunction including loss of mitochondrial membrane potential (MMP) leading to the rupture of the outer membrane which in turn results in the release of mitochondrial apoptotic factors into the cytosol in which cytochrome $\mathrm{c}$ is released, that results in procaspase- 9 activation, and the activation of effector caspasescaspases- 3 resulting in apoptosis [43].

\section{Conclusion}

The administration of curcumin to HepG2 cells resulted in inhibition of cell proliferation. Apoptosis of HepG2 cells induced by curcumin may be stimulated by down-regulation of the expression of ornithine decarboxylase gene. Also, the results revealed the ability of curcumin to induce apoptosis through upregulating P53 gene expression and by stimulating the mitochondrial pathway of cell death through increasing levels of intracellular $\mathrm{Ca}^{2+}$, upregulating the expression level of caspase- 3 gene and decreasing the $\mathrm{Bcl}-2 / \mathrm{Bax}$ ratio. This finding provided a molecular basis for the development of natural compounds as novel anticancer agents for HCC.

\section{Author Contribution}

Tarek M Mohamed shaped this study, Amal H Mahmoudperformed statistical analysis, Abeer A Khamis interpreted of data and drafted the manuscript, and Amira H Sharshar performed the molecular biological experiment. All authors critically revised the manuscript for intellectual and significant contents and approved the final manuscript for submission.

\section{Acknowledgements}

The authors of this study thank all members of the Faculty of Science, Tanta University, Egypt.

\section{Conflicts of Interest}

The authors declare no conflicts of interest regarding the publication of this paper. 


\section{References}

[1] Migliore, L. and Coppede, F. (2002) Genetic and Environmental Factors in Cancer and Neurodegenerative Diseases. Mutation Research, 512, 135-153.

https://doi.org/10.1016/S1383-5742(02)00046-7

[2] Yu, C., et al. (2016) An Updated Dose-Response Meta-Analysis of Coffee Consumption and Liver Cancer Risk. Scientific Reports, 6, Article No. 37488. https://doi.org/10.1038/srep37488

[3] Blonski, W. (2010) Non-Viral Causes of Hepatocellular Carcinoma. World Journal of Gastroenterology, 16, 3603-3615. https://doi.org/10.3748/wjg.v16.i29.3603

[4] Lin, S., Hoffmann, K. and Schemmer, P. (2012) Treatment of Hepatocellular Carcinoma: A Systematic Review. Liver Cancer, 1, 144-158. https://doi.org/10.1159/000343828

[5] Befeler, A.S. and di Bisceglie, A.M. (2002) Hepatocellular Carcinoma: Diagnosis and Treatment. Gastroenterology, 122, 1609-1619. https://doi.org/10.1053/gast.2002.33411

[6] Safarzadeh, E., Sandoghchian Shotorbani, S. and Baradaran, B. (2014) Herbal Medicine as Inducers of Apoptosis in Cancer Treatment. Advanced Pharmaceutical Bulletin, 4, 421-427.

[7] Shanmugam, M.K., et al. (2015) The Multifaceted Role of Curcumin in Cancer Prevention and Treatment. Molecules, 20, 2728-2769.

https://doi.org/10.3390/molecules 20022728

[8] Teiten, M.H., et al. (2010) Curcumin-The Paradigm of a Multi-Target Natural Compound with Applications in Cancer Prevention and Treatment. Toxins (Base), 2, 128-162. https://doi.org/10.3390/toxins2010128

[9] Tayyem, R.F., et al. (2006) Curcumin Content of Turmeric and Curry Powders. Nutrition and Cancer, 55, 126-131. https://doi.org/10.1207/s15327914nc5502 2

[10] Wilken, R., et al. (2011) Curcumin: A Review of Anti-Cancer Properties and Therapeutic Activity in Head and Neck Squamous Cell Carcinoma. Molecular Cancer, 10, 12. https://doi.org/10.1186/1476-4598-10-12

[11] Lv, F.H., et al. (2016) Effects of Curcumin on the Apoptosis of Cardiomyocytes and the Expression of NF-kappaB, PPAR-Gamma and Bcl-2 in Rats with Myocardial Infarction Injury. Experimental and Therapeutic Medicine, 12, 3877-3884. https://doi.org/10.3892/etm.2016.3858

[12] Perrone, D., et al. (2015) Biological and Therapeutic Activities, and Anticancer Properties of Curcumin. Experimental and Therapeutic Medicine, 10, 1615-1623. https://doi.org/10.3892/etm.2015.2749

[13] Chiu, T.L. and Su, C.C. (2009) Curcumin Inhibits Proliferation and Migration by Increasing the Bax to Bcl-2 Ratio and Decreasing NF-kappaBp65 Expression in Breast Cancer MDA-MB-231 Cells. International Journal of Molecular Medicine, 23, 469-475. https://doi.org/10.3892/ijmm 00000153

[14] Choudhuri, T., et al. (2002) Curcumin Induces Apoptosis in Human Breast Cancer Cells through p53-Dependent Bax Induction. FEBS Letters, 512, 334-340. https://doi.org/10.1016/S0014-5793(02)02292-5

[15] Pegg, A.E. (2006) Regulation of Ornithine Decarboxylase. The Journal of Biological Chemistry, 281, 14529-14532. https://doi.org/10.1074/jbc.R500031200

[16] Mohan, R.R., et al. (1999) Overexpression of Ornithine Decarboxylase in Prostate Cancer and Prostatic Fluid in Humans. Clinical Cancer Research, 5, 143-147. 
[17] Kahana, C. (2009) Regulation of Cellular Polyamine Levels and Cellular Proliferation by Antizyme and Antizyme Inhibitor. Essays in Biochemistry, 46, 47-61. https://doi.org/10.1042/bse0460004

[18] Liao, Y.F., et al. (2008) Curcumin Induces Apoptosis through an Ornithine Decarboxylase-Dependent Pathway in Human Promyelocytic Leukemia HL-60 Cells. Life Sciences, 82, 367-375. https://doi.org/10.1016/j.lfs.2007.11.022

[19] Okazaki, Y., Iqbal, M. and Okada, S. (2005) Suppressive Effects of Dietary Curcumin on the Increased Activity of Renal Ornithine Decarboxylase in Mice Treated with a Renal Carcinogen, Ferric Nitrilotriacetate. Biochimica et Biophysica Acta, 1740, 357-366. https://doi.org/10.1016/j.bbadis.2004.09.006

[20] Kulkarni, S., et al. (2012) Extraction and Purification of Curcuminoids from Turmeric (Curcuma longa L.). International Journal of Pharmacology and Pharmaceutical Technology, 1, 81-84.

[21] Lestari, H., et al. (2017) Simultaneous Analysis of Curcumin and Demethoxycurcumin in Curcuma xanthorriza Using FTIR Spectroscopy and Chemometrics. International Food Research Journal, 24, 2097-2101.

[22] Molyneux, P. (2004) The Use of the Stable Free Radical Diphenylpicrylhydrazyl (DPPH) for Estimating Antioxidant Activity. Songklanakarin Journal of Science and Technology, 26, 211-219.

[23] Jiang, J., et al. (2013) Curcumin Disturbed Cell-Cycle Distribution of HepG2 Cells via Cytoskeletal Arrangement. Scanning, 35, 253-260. https://doi.org/10.1002/sca.21058

[24] Livak, K.J. and Schmittgen, T.D. (2001) Analysis of Relative Gene Expression Data Using Real-Time Quantitative PCR and the 2(-Delta Delta C(T)) Method. Methods, 25, 402-408. https://doi.org/10.1006/meth.2001.1262

[25] Macotpet, A., et al. (2013) Oxidative Stress in Cancer-Bearing Dogs Assessed by Measuring Serum Malondialdehyde. BMC Veterinary Research, 9, 101. https://doi.org/10.1186/1746-6148-9-101

[26] Weydert, C.J. and Cullen, J.J. (2010) Measurement of Superoxide Dismutase, Catalase and Glutathione Peroxidase in Cultured Cells and Tissue. Nature Protocols, 5, 51-66. https://doi.org/10.1038/nprot.2009.197

[27] Aebi, H. (1984) Catalase in Vitro. Methods in Enzymology, 105, 121-126. https://doi.org/10.1016/S0076-6879(84)05016-3

[28] Paglia, D.E. and Valentine, W.N. (1967) Studies on the Quantitative and Qualitative Characterization of Erythrocyte Glutathione Peroxidase. The Journal of Laboratory and Clinical Medicine, 70, 158-169.

[29] Zhang, H.H., et al. (2018) Metformin in Combination with Curcumin Inhibits the Growth, Metastasis, and Angiogenesis of Hepatocellular Carcinoma in Vitro and in Vivo. Molecular Carcinogenesis, 57, 44-56. https://doi.org/10.1002/mc.22718

[30] Chang, M., Wu, M. and Li, H. (2017) Curcumin Combined with Glycyrrhetinic Acid Inhibits the Development of Hepatocellular Carcinoma Cells by Down-Regulating the PTEN/PI3K/AKT Signalling Pathway. American Journal of Translational Research, 9, 5567-5575.

[31] Shariati, M., et al. (2017) Nanocurcumin-Mediated Down-Regulation of Telomerase via Stimulating TGFbetal Signaling Pathway in Hepatocellular Carcinoma Cells. Iranian Biomedical Journal, 22, 171-179.

[32] Gallardo, M. and Calaf, G.M. (2016) Curcumin and Epithelial-Mesenchymal Transition in Breast Cancer Cells Transformed by Low Doses of Radiation and Estrogen. 
International Journal of Oncology, 48, 2534-2542.

https://doi.org/10.3892/ijo.2016.3477

[33] Lee, D.S., Lee, M.K. and Kim, J.H. (2009) Curcumin Induces Cell Cycle Arrest and Apoptosis in Human Osteosarcoma (HOS) Cells. Anticancer Research, 29, 5039-5044.

[34] Zhu, Y. and Bu, S. (2017) Curcumin Induces Autophagy, Apoptosis, and Cell Cycle Arrest in Human Pancreatic Cancer Cells. Evidence-Based Complementary and AIternative Medicine, 2017, Article ID: 5787218. https://doi.org/10.1155/2017/5787218

[35] Das, L. and Vinayak, M. (2015) Long Term Effect of Curcumin in Restoration of Tumour Suppressor p53 and Phase-II Antioxidant Enzymes via Activation of Nrf2 Signalling and Modulation of Inflammation in Prevention of Cancer. PLoS ONE, 10, e0124000. https://doi.org/10.1371/journal.pone.0124000

[36] Li, W., et al. (2015) A Preliminary Study of the Effect of Curcumin on the Expression of p53 Protein in a Human Multiple Myeloma Cell Line. Oncology Letters, 9 , 1719-1724. https://doi.org/10.3892/ol.2015.2946

[37] Chen, H.W. and Huang, H.C. (1998) Effect of Curcumin on Cell Cycle Progression and Apoptosis in Vascular Smooth Muscle Cells. British Journal of Pharmacology, 124, 1029-1040. https://doi.org/10.1038/sj.bjp.0701914

[38] Khazaei Koohpar, Z., et al. (2015) Anticancer Activity of Curcumin on Human Breast Adenocarcinoma: Role of Mcl-1 Gene. Iranian Journal of Cancer Prevention, 8, e2331. https://doi.org/10.17795/ijcp2331

[39] Jiang, A.J., et al. (2015) Curcumin Induces Apoptosis through Mitochondrial Pathway and Caspases Activation in Human Melanoma Cells. Molecular Biology Reports, 42, 267-275. https://doi.org/10.1007/s11033-014-3769-2

[40] Song, G., et al. (2005) Curcumin Induces Human HT-29 Colon Adenocarcinoma Cell Apoptosis by Activating p53 and Regulating Apoptosis-Related Protein Expression. Brazilian Journal of Medical and Biological Research, 38, 1791-1798. https://doi.org/10.1590/S0100-879X2005001200007

[41] Huang, Y.F., et al. (2017) Curcumin Enhances the Effects of Irinotecan on Colorectal Cancer Cells through the Generation of Reactive Oxygen Species and Activation of the Endoplasmic Reticulum Stress Pathway. Oncotarget, 8, 40264-40275. https://doi.org/10.18632/oncotarget.16828

[42] Xu, X., et al. (2015) Curcumin Induces the Apoptosis of Non-Small Cell Lung Cancer Cells through a Calcium Signaling Pathway. International Journal of Molecular Medicine, 35, 1610-1616. https://doi.org/10.3892/ijmm.2015.2167

[43] Giorgi, C., et al. (2012) Mitochondrial $\mathrm{Ca}^{2+}$ and Apoptosis. Cell Calcium, 52, 36-43. https://doi.org/10.1016/j.ceca.2012.02.008 